\title{
The Rights of Women in Islam and Some Misconceptions: An Analysis from Bangladesh Perspective
}

\author{
Manjur Hossain Patoari \\ Department of Law, International Islamic University, Chittagong, Bangladesh \\ Email: manjuiiuc3@yahoo.com
}

How to cite this paper: Patoari, M. H. (2019). The Rights of Women in Islam and Some Misconceptions: An Analysis from Bangladesh Perspective. Beijing Law Review, 10, 1211-1224.

https://doi.org/10.4236/blr.2019.105065

Received: September 16, 2019

Accepted: November 30, 2019

Published: December 3, 2019

Copyright $\odot 2019$ by author(s) and Scientific Research Publishing Inc. This work is licensed under the Creative Commons Attribution International License (CC BY 4.0).

http://creativecommons.org/licenses/by/4.0/ (c) (i) Open Access

\begin{abstract}
Allah (SWT) has created both men and women without subordination of one another. Islam has ensured gender equality and women's rights in every sphere of their life. Islam has guaranteed rights of men and women in an equal degree and there is no discrimination between men and women. But due to the prevailing socio-cultural norms and practices in Bangladesh sometimes the guarantee of Islam do not get translated into tangible actions. Islam is the religion which liberated Muslim women by ensuring equal rights to them in comparison to their male fellow. There are some misconceptions prevailing in Bangladesh regarding women's rights in Islam. Sometimes Muslim women themselves falsely knew that they are backward and oppressed by their religion. Some make great mistake in presuming that all conduct and practices of a Muslim are connected to Islam. The prime object of this study is to pick out how rights of women are ensured in Islam. This study concludes with an allusion that women are not subordinate of men and indicate an avenue to identify properly women in the light of Islam. This research is actually qualitative in nature where only secondary data has been used. Analytical method was also used in this research. Data has been collected from various books, journals, holy Qur'an and sunnah (tradition) of the Prophet (peace be upon him). This research finds that Islam does not deprive the women rather ensuring proper rights, dignity and status but due to lack of proper Islamic knowledge and awareness and sometimes to dominate or neglect some misconceptions prevailing in Bangladesh. To eliminate prevailing misconceptions regarding women rights in Islam proper Islamic knowledge and awareness of the women is essential. The core implication of this research is that it will play a vital role to eliminate prevailing misconceptions regarding women rights in Islam and to ensure the rights, dignity and status of women as given in Islam. This study will open a new avenue for scholars who will be
\end{abstract}


able to contribute their knowledge and wisdom to ensure the position of women as given in Islam. This research includes only those rights of the women as guaranteed by Islam and it does not include constitutional rights or other rights ensured by the existing laws of the country.

\section{Keywords}

Women's Rights, Gender Equality, Women's Freedom, Islam, Misconceptions

\section{Introduction}

Undoubtedly, there is no discrepancy in Islam between men and women as far as their relationship to Allah in concerning as both are promised the same reward for good conduct and the same punishment for evil conduct. Allah says:

"And for women are rights over men similar to those of men over women." (2: 228)

The holy Quran, in addressing the believers, often uses the expression "believing men and women" to accentuate the equality of both male and female in regard to their particular duties, rights, virtues and merits. Islam is such a religion which has first given to the women a place of dignity and honour because before the advent of Islam, there were huge discriminations towards women. Islam abolished inhumanity, inequality, discrimination towards women as well as gave a complete code of conduct for both male and female. Prior to the arrival of Islam, the pagan Arabs used to bury their female children alive, make women dance naked in the vicinity of Ka'ba during their annual fairs and treated women just like slaves or chattels and they used women only for their sexual contentment who possess no rights, dignity, honour or position (Doi, 1992). Unlike other religions, which regarded women as being possessed of inherent sin and wickedness and men are being possessed of inherent virtue and nobility, Islam treats men and women as being of the equal essence created from one soul. Allah says:

"O mankind, be mindful of your duty to your Lord, who created you from a single soul and from it created its mate and from the two created and spread many men and women". (4: 2)

To understand the rights, honour, dignity and status of women in Islam, it is sufficient to judge the position of women before the advent of Islam. At that time, they were like slaves and most often their positions were worse than animals. The Prophet (peace be upon him) proposed to stop any sorts of torture, cruelty or inhuman to women. He showed greatness towards them. He advised the Muslims: "Fear Allah in respect of women." And: "The best of you are them who behave best to their wives." And: "A Muslim must not hate his wife, and if he is displeased with one bad quality in her, let him be pleased with one that is good." And: "The more civil and kind a Muslim is to his wife, the more perfect 
in faith he is" (Doi, 1992). The Prophet (peace be upon him) was very much forceful in enjoining upon Muslims so that they are kind to the women. In his Farewell Pilgrimage (Hajj al-Wada), he directed those present, and through them all those Muslim whoever to came later, to be courteous and kinds towards women. He said: "Fear Allah regarding women. Verily you have married them with the trust of Allah, and made their bodies lawful with the word of Allah. You have got (rights) over them, and they have got (rights) over you in respect of their food and clothing according to your means" (Doi, 1992). In Islam spiritual equality have guaranteed for both men and women (Orakzai, 2014). Allah says, "Whoso does good whatever male or female, and is a believer, shall enter Paradise and they shall not be wronged a whit." (4:125)

But currently in many Muslim communities women are not consider according to the rights given them in Islam. In many societies Muslim are practicing their own cultures and customs and women are being subject to cultural issues, patriarchal features of their society and also political oppression (Sechzer, 2004). In Bangladesh as majority of the people are Muslim, Islam plays a significant role in the country. Although Quran and the tradition of the Prophet (peace be upon him) emphasis on gender equality and rights, dignity and status of women but somebody use it for exploiting and discriminating against women after tempering some verses of the text to dehumanize them (Khanum, 2008).

In Bangladesh many misconceptions prevailing regarding women's rights due to proper religious knowledge, misinterpretation of Quran and the tradition of the Prophet (peace be upon him). The power to explain the religious rules is preserved by men in Bangladesh as women are not so qualified in religious knowledge and for this reason patriarchal importance is reflected and sometimes it is politicized as the Ulema (religious scholars) are mostly men (Siddika, \& Khatun, 2014). Due misconceptions and misinterpretations of Islamic rules women are being deprived of their rights, dignity, honour and status as given them in Islam and sometimes are being subject of oppression. To prevent domination of male, women's subordination and to ensure rights of women in Bangladesh as given in Islam by abolishing misconceptions about women's rights proper religious knowledge as well as awareness of women is essential.

\section{Rights and Status of Women Prior to the Advent of Islam}

In the pagan society of pre-Islamic Arabia the status of women was like slaves who had no rights and dignity. Women would not get share either from parents or spouse as inheritance. But Islam ensures share of women in the property of parents and husband (Rahman, 2008). Regular shape of marriage as we understand at present time was totally absent. There were such types of marriage as may be treated as fornication, prostitution, adultery or polyandry (Faiz-ud-din, 2008). Men could marry any number as he like and there were no specific rules in regard to marriage, they could marry even two real sisters at one and at the same time (Rashid, 2004). But in case of marriage, Islam imposes prohibition on 
account of affinity (prohibition due to marriage relationship). In this respect the Holy Qur'an declares:

"Forbidden for you (to marry) are the mothers of your wives and your step-daughters that are in your laps (in charge of you) through your wives to whom you have gone in; but if you have not gone in to them, then there is no sin upon you (to marry them); and the wives of your sons whom you have begotten." (4: 23). Husband possessed the power of divorce which was so unlimited and unrestricted that he could divorce his wife whenever he wishes without any lawful ground and could revoked his divorce and divorce again as many times as he favored. He could illogically accuse his wife of falseness, dismiss her and leave her with such infamy as would prevent other suitors; while he himself would go free from any kinds of liability of maintenance or legal punishment. Neither of the wives could get a dower but Islam approves dower as a respect to the wife (Faiz-ud-din, 2003). False charges of unchastely were frequently used for depriving the wife from her right of dower. Her protector could deliver her to any person as he wished. But showing respect to women Islam reformed marriage laws in a sweeping and far-reaching way.

Women were considered as material things and where husband were unable to pay his debt during his life time, after his death his creditor would own his wife as reparation (Saifee, Baloach, Sultan, \& Khalid, 2012). Female child were considered an evil omen and fathers were terrified if the new born baby were female. Fathers not only become unhappy when a female child was born but also felt embarrassed. In pre-Islamic Arabia, there was a ridiculous discrimination against their female children whom they used to bury alive. The Messenger of Allah (peace be upon him) not only protest to this culture but also ordered to stop it. He showing them that supporting their female children would act as a screen for them against the fire of Hell (Doi, 1992).

Under original Hindu law, women were treated like slave who had no rights of inheritance (Uddin, \& Hossain, 2017). If the husband of woman died during her lifetime then she had to burn herself alive when the dead body was cremated (Doi, 1992). Widow had no right to remarry who had to bear intolerable pain in her daily life. In Chinese culture, there were many atrocious customs had to bear a girl. A male child was treated as an immense gift of God but female was an acceptable degradation (Saifee, Baloach, Sultan, \& Khalid, 2012). In Greek society, women were treated to be the incarnation of evil and they had no right of inheritance, education, divorce etc. (Saifee, Baloach, Sultan, \& Khalid, 2012). They were considered as material goods who had no feelings and free will. In ancient Rome, cruelties towards women were unbearable. Women had no rights, dignity or honour and the position of the women was like slave (Kabir, 2009). Men had authority to sell her or send her into exile even a husband had power of summarily putting his wife to death for acts like drinking, poisoning and substitution of a spurious child (Doi, 1992). In Jewish society, women were lived without right, dignity and honour. They had no right of inheritance and were considered as an object owned by the male protector. 


\section{Rights, Dignity, Honour and Status of Women in Islam}

Islam does not allow the domination of men over women rather it upholds the rights, dignity, honour and status of women by ensuring gender equality and also equality of rights for both male and female in every area of human life. In Islam a woman is completely self-regulating who has legal personality and who is able to enter into contract or can make bequest in her own name. She has right to perform any profession or business and has authority to dispose her property as like as men. She is entitled for inheritance in different capacity like as mother, as wife, as sister and as daughter. She has full freedom to select her husband and also allowed to her dower and maintenance. As the command of Islam to the men is to treat with compassion and full respect to their wives, women are respectable and honourable in Islam (Mohammad, \& Lehmann, 2011). A women as mother has immense respect in Islam than any other person. The holy Quran in many verses commands Muslims to demonstrate respect to their mothers and serve them well even if they left Islam and are still remain as unbelievers. The prophet (peace be upon him) states insistently that the rights of the mother are supreme (Doi, 1992). In Islam women are most respectable and honorable "if she is a wife, she is life partner, if she is as a mother, the paradise is under the feet of mother, if she is daughter it is blessing of Almighty Allah" (Soomro, \& Khuhro, 2018). The different types of rights of women ensured in Islam are:

\subsection{Inheritance}

The pre-Islamic customs relating to succession were biased, vindictive, and unreasonable and in most of the cases violated justice (Akter, Rahman, \& Dolon, 2012). Women were treated as property and they were not entitled to inheritance whether as mother or wife or daughter or sister. There was no specific system for cognates and agnates and always males could get preferences. There were established traditions that the nearest male agnates succeeded to the entire estate of the deceased and females and cognates were excluded (Rashid, 2004). Islam ensured the rights of inheritance of women many centuries ago than western countries (Sechzer, 2004). In Islam six classes of persons never deprive from inheritance (Faiz-ud-din, 2008). Among these six classes of persons, three classes of persons are male (father, husband and son) and rest three are female (mother, wife and daughter). In Islamic law of inheritance, among twelve sharers (called Quranic sharer whose share is define in Quran) numbers of women are eight ("wife, mother, daughter, son's daughter, true grandmother, full sister, consanguine sister and uterine sister") and the numbers of men are four (father, husband, true grandfather and uterine brother) (Haque, 2009). So Islam does not neglect women giving more importance to men.

In case of right of inheritance of a woman as mother three situations may arise. She may be entitle either 1/6 (if the deceased person has a child or son's child how low so ever or two or more brothers or sisters) or 1/3 (if the deceased person do not have any child or son's child or not more than one brother and 
sister) or $1 / 3$ of residue (if the deceased person have wife or husband and father) (4:11). As wife two situations may arise and she may be entitle either 1/4 (if the deceased person have child or son's child how low so ever) or 1/8 (if the deceased person do not have any child or son's child) of the property of the deceased. (4:12). As daughter, if only one daughter and no son her share is $1 / 2$ and if two or more daughters and no son their share is $2 / 3$ and if there is son daughter will be residue and each daughter will get half of son. (4:11). Besides this, parents could distribute property equally between a son and a daughter (Khanum, 2008). Islam is the only religion that does not deprive women from their right of inheritance rather ensured right of inheritance of women.

\subsection{Marriage}

Allah has created men and women as company for one another and so that they can procreate and live in peace and tranquility according to the commandments of almighty Allah and the directions of His Messenger. Allah says:

"And among His signs is this that He created for you mates from among yourselves, that you may dwell in tranquility with them, and He has put love and mercy between your hearts. Undoubtedly in these are signs for those who reflect." (30:21)

Marriage is treated as the basis of social life and the beginning of the family life. It is compulsory (Wajib) for a man who has the means to easily pay the dower (Mahr) and to bear the expenses of a wife and children, and also physically fit, and doubts that if does not marry, he may be allured to commit adultery (Zina) and also obligatory for a woman who do not have any other legal way of maintaining herself and who doubts that her sexual urge may move forward her into adultery (Doi, 1992). It protects society and safe guard human being from foulness and un-chastity (Akter, Rahman, \& Dolon, 2012).

In Islam marriage is an act for the pleasant of Allah because it is according to His orders that husband and wife love each other and help each other to make efforts to continue the human race and rear and foster their children to become true servant of Allah. As it is also the biological instincts to have sexual intercourse, marriage is not only satisfying sexual lust of men and women but also preserve future generation (Hidayatullah \& Hidayatullah, 1990).

In case of marriage, Islam has given equal importance both bride groom and bride as for being a valid marriage any party may offer to the other party and it must be accepted by the other party (Rashid, 2004). Through valid marriage mutual right of inheritance are established and wife become entitle to her dower and maintenance. But marries does not give power to the husband over the wife's person beyond the limit of law and right upon her goods and property (Hidayatullah \& Hidayatullah, 1990). In marriage in Islam women are at liberty to choose their life partner. Nobody can force her to choose her mate or to marry even one's father, mother, brother, sister or any paternal or maternal guardian. Marriage of major woman previously married without her consent is un- 
animously void and of a major virgin girl without her consent is unlawful (Faiz-ud-din, 2008). Islam showed full respect to the women and ensured rights, dignity and honour and equal status of men and women in case of marriage because for being a valid marriage acquiescence of the bride groom as well as bride is mandatory. In this regard no one is superior.

\subsection{Dower}

In pre-Islamic period dower was paid to the wife's father or other guardian, which was used to signify gifts (sadaka) and could therefore be regarded as sell price in present time. Islam approved dower (mahr) to be paid to the wife in case of regular marriage as respect to the wife and not as sell price. Dower may be a sum of money or any other kind of property of which the wife is legally entitled to get from the husband as a token of respect. It cannot be treated as consideration or exchange given to the wife for entering into marriage contract.

Islam has given importance for the payment of dower and also imposed duty on the husband to pay dower to the wife. The holy Quran states, "Give women (wives) their dower with no strings attached. If they themselves (wives) give some of it back to you (waive it), then consume it (dower) with good cheers." (4:4). The Prophet (peace be upon him) said, "Pay dower (mahr) to your wife even it is a ring made of iron" (Faiz-ud-din, 2008). According to the provision of Islam, husband must have to pay dower to the wife either in cash or any other form and husband has no way to deny his liability except paying dower. It may be prompt or deferred.

It is like a debt or duty for the husband to pay dower and a right of the wife to receive it. In case of dower Islam has showed respect and given full authority to the wife as she can demand her dower at any time without any explanation and can waive full or any part of her dower as she like and no one can interfere in this matter. Islam has given rights to the wife and imposed duty on the husband if the amount of dower was not settled during the time of marriage or later on, the wife is entitled to proper dower, though the marriage was completed on the stipulation that the wife cannot demand any dower (Hidayatullah \& Hidayatullah, 1990). In determine the amount of proper dower, the social position of the wife's family, financial condition of the husband, personal qualifications of the bride and dower settled upon the female members of the family of the bride's father will be consider. Under Islamic law, where there is a marriage there is a dower whatever may be the amount and it is bridal gift (Akter, Rahman, \& Dolon, 2012). According to the direction of the Prophet (peace be upon him) if anybody do not pay the dower in the Day of Judgment he will be treated as adulterate. Islam has ensured the right of dower of a woman and given her unlimited and unrestricted power to dispose her dower in any lawful way as she like.

\subsection{Maintenance}

Maintenance (nafaqa) is very significant issue in Muslim personal law. To afford 
maintenance is not only legally approved but also it is an act of devotion (iba$d a t)$. Under Muslim law, maintenance is due to the wife from the husband as a recompense for the matrimonial restraint and is one of the necessary and inherent conditions of the marriage contract. Husband responsibility is to provide proper maintenance and it is such a duty that must be discharged cheerfully without any censure, hurt or patronization (Faiz-ud-din, 2008). The holy command "Let him provide her (wife) maintenance according to his ability". (65:7). It is duty upon the husband to provide proper food, cloth and accommodation if she surrenders herself to him although she is Muslim or infidel or poor or rich, grown-up or young (Rashid, 2004).

Muslim husband is legally bound to provide maintenance to his wife so long as she is truthful to him and observe his lawful orders whether she is poor or rich will not be considered. Maintenance is one of important legal rights of the wife and a legal duty of the husband who will not be exempted from this liability whatever may be his financial condition. A wife can demand maintenance during her sickness in her husband's house and even if a man divorces his wife her bread and accommodation are attributed upon him during the period of iddat (remaining unmarried for a period of three months after dissolution of marriage) whether the divorce is of reversible or irreversible kind. The wife becomes entitle for maintenance immediately after valid marriage and husband cannot deny his liability of providing maintenance. When there subsists a valid marriage there must have a right of maintenance by the wife. Islam does not impose liability upon the wife to bear expenses of the family or to bear expenses of her husband on any condition rather ensured her right to get maintenance from her husband.

In Bangladesh currently there are two statutes containing provisions regarding the maintenance of wife. Section 5 of the Family Courts Ordinance, 1985 (Ordinance No- XVIII of 1985) states that every family court is competent to entertain, try and dispose of any suit relating to the dower and maintenance of a woman. Section 9 of the Muslim Family Laws Ordinance, 1961 (Ordinance NoVIII of 1961) runs: "If any husband fails to maintain his wife adequately or where there are more wives than one, fails to maintain them equitably, the wife or all or any of the wives may, in addition to seeking any other legal remedy available, apply to the chairman who shall constitute an arbitration council to determine the matter, and the arbitration council may issue a certificate specifying the amount which shall be paid as maintenance by the husband and the amount fixed by the council is recoverable as arrears of land revenue. Of course, an aggrieved party may prefer an appeal to the court of assistant judge whose decision is final and no appeal shall lie in any court of law."

\subsection{Divorce}

In the Dark Age, when Islam does not emerge in Arabs, only the husband had power of divorce and which was so unrestricted and unlimited that he practiced 
in the most inhuman ways. Husband could divorce his wife whenever he like without any legal or reasonable cause. He had also the power to revoke his divorce and divorce again as many times as he favored. He could, moreover, if he so desired, swear that he had made no sexual relation with his wife, though still living with her. The husband exercised limitless rights over the wife. If a man became angry with his wife, whether for any reasonable cause or just to satisfy his caprice, he could divorce her at once, but the unfortunate wife could neither have recourse to any legal procedure nor get any maintenance from him nor claim any other kind of right from him. Regarding right of divorce men enjoyed vast powers who could easily get rid of his wife by leveling a flimsy charge against him.

The Prophet (peace be upon him) looked upon these evil customs of divorce with tremendous dissatisfaction and regarded their practice as considered to damage the foundation of society. It was quite impossible to abolish this evil custom completely. The Prophet (peace be upon him) had to mould the mind of an uncultured and semi-barbarous community to a higher development. In case of extreme emergency, Islam permitted divorce if all efforts of bringing together have unsuccessful. Islam recognized that when it has become impossible to continue conjugal life it is better for both husband and wife to separate harmoniously rather than miserably bound together which turns the home into a hell.

The rectification of Prophet Mohammad marked a new departure in the history of Eastern legislation. He reserved unrestricted power of divorce by the husband but also given to the wife the right of obtaining the partition on rational grounds. Though divorce is allowed in Islam with some conditions it discourages dissolution of a marriage-tie as Prophet (peace be upon him) says: "Of all things that Islam has permitted, divorce is the most hated by Allah." ( $A b u$ $\left.D a^{\prime} u d\right)$. Islam has given to the women right regarding dissolution of marriage by:

1) Delegated divorce (Talaque-e-tafweez): Though the husband possesses primarily the power of divorce wife also may exercise this right to dissolve her marriage if the husband delegates the power of dissolution of marriage to the wife (Soomro \& Khuhro, 2018). This delegation of power can be during the marriage or at any time after marriage. The power so delegated to the wife is irrevocable and it can be exercised even after the institution of a suit by the husband against her for restitution of conjugal rights.

2) Redemption (KhuP a): It means a mutual agreement between husband and wife where both of them agree to break off their marriage in lieu of a recompense paid by the wife to her husband out of her property (Faiz-ud-din, 2008). If the relationship of a husband and a wife is not fine, the wife has a right to seek divorce (khul a) by renouncing her claim to the dower (Rashid, 2004). According to the Prophet (Sm) of Islam, "If a woman be prejudiced by a marriage, let it be broken."

3) Mutual release (Mubar' at): When both the parties of a marriage feel aversion, they have liberty to release each other without any claim upon the other. In 
this form of divorce both of the parties to the marriage has right to offer and the other party has right to accept and when it is accepted marriage will be dissolved and it is an irrevocable divorce (Hidayatullah \& Hidayatullah, 1990).

\subsection{Right to Choose Profession}

In Islam like men women have various responsibilities towards the family and society as she is considered one of the two important pillars of the society. Islam does not like laziness, vanity and workless people. In Islam there is no difference between men and women in regard to work and working is a duty for both. In Islam women have freedom to choose their occupation but in choosing their profession they must keep in mind that they have some limitations due to their physical structure. As they are exquisite, sensitive beautiful beings they have to be more conscious before involving any profession. Though in Islam women have liberty to select their profession but it impose some restrictions at the same time because a married woman cannot choose any profession by which her husband will be deprived to enjoy his conjugal rights or children will be deprived from maternal love, care and affection and proper education and training.

\subsection{Right to Proprietorship}

In regard to ownership of property Islam has given equal respect to the women like men. She may gain property through lawful means and become owner and she has also right to dispose of that property in any legal way as she wishes. Nobody whether father or husband or mother or even her children have no right to interfere her regarding her property. It is not her responsibility to bear expense of the family even her maintenance or maintenance of the children. Husband has no right in her personal property. She is not liable to pay the debt of her husband. But in case of necessity he may take loan from her and in that case she will have all rights of a creditor.

\subsection{Right to Seek Knowledge}

In Islam acquiring knowledge is obligatory for both men and women. In this regard an unmarried woman has full freedom to acquire knowledge and nobody can obstruct her from acquiring knowledge. A married woman also has right of acquiring knowledge but she must observe the right of her husband and children.

\subsection{Right to Involve in Politics}

Islam ensured political independence of men and women. There is opportunity for a woman to involve in politics (Rezvani, 2013). She can participate in political convention, street demonstrations, congregations and Friday prayers. She has right to self defense and defends her property and even she can participate in war to defend the sovereignty of her own country. But for all these she has to follow the directions of Islam. 


\subsection{Right to Choose Residence}

A woman has freedom to choose residence for herself. In Islam, as it is the liability of husband to provide proper maintenance to his wife, a married woman must stay to her husband's place of residence. Considering the ability and benefit of her husband a married woman can select her residence in such place as dignity of the family is properly maintained. According to the direction of Islam she cannot claim her residence in such place which will be some hardship for her husband.

\subsection{Economic Rights of Women}

A Muslim woman is allowed to involve herself in economic activities following some rules. The women who are highly talented and have the opportunity to acquire higher degree can render services for the betterment of the society, particularly in the teaching profession. But here too, a strict Islamic code of conduct has to be observed in the classroom. As for medical profession, women doctors are badly needed in the field of gynecology and obstetrics. Usually women feel shy and even forbidden by Islam from consulting male doctor as per as possible in their ante-natal and post-natal treatment but if it is a question of life and death then in special circumstances it is permitted. In Islam women are encourages in medical profession. Women can involve in welfare institutions of the society. With her Allah-given touch of loving and affection she can handle juvenile delinquents, drop-outs from schools frustrated youths. Even she has right to work in a factory if it is run by women.

Woman is not forbidden to go out of her home for necessity. In the time of the Prophet (peace be upon him), women went out to the market or their farms. The prophet (peace be upon him) did not stop a woman in her iddat from going out of her house in case of necessity. Jabir ibn Abdullah says husband of my aunt divorced her and when she was spending her iddat in the house she wanted to go outside of the house to get some of her date palms harvested and sold. Someone halted her, saying that you are not allowed to go out of the house during iddat. She went to the Prophet (peace be upon him) to whether she could go outside of the house or not and the Prophet (peace be upon him) said, "You go out and get the date trees harvested (and sold) so that you may be able to do some other good work." (Abu Da'ud).

\section{Prevailing Misconceptions in Bangladesh Regarding Women Rights in Islam}

Some misconceptions regarding women's rights in Islam are prevailing in Bangladesh for long time. These misconceptions directly neglect the women, dishonored them and discriminate them. Some people without proper religious knowledge, to dominate the women, to deprive women from their rights as given in Islam and to establish superiority of men over women practice these misconceptions as rule of Islam. But Islam does not support these misconceptions 
these are direct contradiction of Islamic rules and principles. Some misconceptions regarding women rights prevailing in Bangladesh are:

1) "Islam deprived women as in inheritance they are getting half share as compared to men". There is a misconception in Bangladesh that Islam deprived women in case of right of inheritance. But most of the people do not realize what the place of women in Islam is. In Islam, from the property of her parents a woman is entitled to get $1 / 2$ of the share as compared to her brother but she has no financial liability towards the family. She is entitled to her dower, to get gifts during her marriage and she is not required to spend her income to bear the expenses of the family. Her all expenses are bear by father before marriage and by the husband after marriage (Orakzai, 2014). Besides these, she has right of inheritance in the property of her husband and also in the property of the children.

2) "Unconditionally a man can take four wives at a time". Another misconception prevailing in Bangladesh regarding polygamy. According to the rules of Islam, maximum four wives might be taken by a man at one time only when he possessed the strength of character to deal justly with them. The holy Quran says:

"If you fear that you will not able to deal justly with the orphans, marry women of your choice, two or three or four, but if you fear that you will not be able to deal justly with them, then only one." (4: 3).

The above rule on polygamy is conditional. The verse specially refers to the justice to be done to orphans. It was revealed immediately after the Battle Uhud when the Muslim community was left with many orphans and widows and some captives-of-war. The treatment was to be governed by principles of greatest humanity and equality. If a man wants to take more than one wife he should have sufficient financial resources to look after the needs of the additional wives that he has taken and he must do equal justice with them in regard to the fulfillment of their conjugal and other rights (Doi, 1992). The logic to justify polygamy is that it prevents divorce of the sick, older and barren wife and to refrains men from extra-marital relationship and also remove social hypocrisy (Marcotte, 2003).

3) "Consent of bride is not so important for marriage". Male dominated societies of Bangladesh do not want to give equal importance of the consent of bride like bride groom in case of marriage. They think that consent of the father or guardian is final for the marriage of a girl but Islam does not support it. According to Islam, for a valid marriage free consent of the bride and bride groom is required. Islam has given right of a woman to choose her life partner.

4) "No marriage without dowry". The most heinous practice in Bangladesh which Islam never supports is dowry system. It has become such social practice in Bangladesh that sometimes marriage cannot imagine without dowry. Some greedy people established system in the society that wife have to bring wealth from her parents and sometimes they torture physically or mentally and even sometimes causes death of the wife by torture for dowry (Ahmed, 1997).

5) "Women have no right of divorce in Islam". Though in Islam husband 
has absolute power to divorce but he may delegates this power to the wife. According to Islam both husband and wife can separate by mutual understanding. Besides these, she may demand separation by relinquishing all claims to the husband.

The main reasons of prevailing misconceptions in Bangladesh regarding women rights in is Islam are firstly not having proper knowledge regarding rules and regulations of Islam; secondly to dominate the women and to establish superiority of men over women; thirdly to deprive the women from their legal rights as given them by Islam; fourthly illiteracy of women and lack of awareness among women are one of the main reasons of misconceptions regarding women rights in Islam; fifthly to neglect the women and to dishonor them and to discriminate them; as most of the religious interpreters are male.

\section{Conclusion}

Islam is the complete and comprehensive code of life which covers all aspects of human life from cradle to grave. Allah has created both male and female for worship and thralldom and to play distinct roles in the society but there is no superiority between them except on the ground of morality. Islam has guaranteed the rights of women in every sphere of life like men. It is only the religious which does not discriminate between men and women. It also does not allow the domination of men over women. In the Dark Age, when women were treated as material things and who had no rights and if the husband of a woman died during her lifetime, then she had to burn herself alive when the dead body was cremated and then Islam not only protected the women but also gave them right, dignity and honour. Islam does not impose any financial liability on the women rather ensuring her right of dower, maintenance and inheritance. Islam does not treat women "an instrument of the Devil". In Islam, she has freedom to involve herself in any social and economic activities and even in politics. But in male dominated society of Bangladesh, some misconceptions are prevailing regarding women rights in Islam due to lack of proper religious knowledge, lack of awareness of women regarding their rights as given in Islam, the prevailing customs and also for dominating mentality of men. Sometimes to deprive the women or to dishonor the women or to blaspheme the women or for financial interest or for political interest, men practice some bad customs and claim these are the rules of Islam but Islam never supports these bad practices. Due to the lack of proper Islamic knowledge, sometimes women also blamed the Islam injustice to them or dishonored them or deprived them. To know the rights of women in Islam and to understand the actual position of women in Islam and to eliminate the prevailing misconceptions regarding women's rights in Islam, proper Islamic knowledge and awareness of women is essential and also necessary to change the dominating mentality of the men.

\section{Conflicts of Interest}

The author declares no conflicts of interest regarding the publication of this paper. 


\section{References}

Ahmed, G. (1997). Women's Rights and Family Values. Islamic and Modern Perspective. Dhaka: Era Enterprise.

Akter, S., Rahman, A. N. M. A., \& Dolon, M. J. H. (2012). Muslim Law. Dhaka: Hira Publication.

Doi, A. R. (1992). Women in Shari ah (Islamic Law) (4th Ed.). Kula Lumpur: A. S. Noordeen.

Faiz-ud-din, M. (2003). Muslim Marriage and Statutory Law (2nd Ed.). Rajshahi: Aligor Library.

Faiz-ud-din, M. (2008). A Text Book on Islamic Law. Dhaka: Shams Publications.

Haque, M. E. (2009). Islamic Law of Inheritance (Rules and Calculations). Dhaka: London College of Legal Studies.

Hidayatullah, M., \& Hidayatullah, A. (1990). Principles of Mahomedan Law (19th Ed.). Bombay: N. M. Tripathi Private Ltd.

Kabir, L. (2009). Roman Law(4th Ed.). Dhaka: Ain Prokashan.

Khanum, R. A. (2008). Feminism Status of Women and Islam. Empowerment, 15, 67-78.

Marcotte, R. D. (2003). How Far Have Reforms Gone in Islam? Women's Studies International Forum, 26, 153-166. https://doi.org/10.1016/S0277-5395(03)00017-7

Mohammad, I. J., \& Lehmann, C. (2011). Women's Rights in Islam Regarding Marriage and Divorce. Journal of Law and Practice, 4, 1-13.

Orakzai, S. B. (2014). The Rights of Women in Islam: The Question of "Public" and "Private" Spheres for Women's Rights and Empowerment in Muslim Societies. Journal of Human Rights in the Commonwealth, 2, 42 -51. https://doi.org/10.14296/jhrc.v2i1.2100

Rahman, M. M. (2008). Introduction to Muslim and Family Law. Dhaka: Kamrul Book House.

Rashid, S. K. (2004). Muslim Law (3rd Ed.). Lucknow: Eastern Book Company.

Rezvani, A. (2013). Review of the Economic and Political Rights of Women Based on Islam's View. International Research Journal of Applied and Basic Sciences, 4, 187-190.

Saifee, A., Baloach, A. G., Sultan, S., \& Khalid, I. (2012). Status, Identity and Privileges of Women in Islam. European Journal of Social Sciences, 30, 146-154.

Sechzer, J. A. (2004). "Islam and Women: Where Tradition Meets Modernity": History and Interpretations of Islamic Women's Status. Sex Roles, 51, 263-272.

https://doi.org/10.1023/B:SERS.0000046610.16101.e0

Siddika, M. T., \& Khatun, M. (2014). Re-Reading Muslim Women's Rights in Bangladesh. Journal of the Asiatic Society of Bangladesh, 59, 323-341.

Soomro, Z. H., \& Khuhro, A. A. (2018). Women Rights in Islam. International Journal of Scientific \& Engineering Research, 9, 272-285.

Uddin, M., \& Hossain, M. F. (2017). A Text Book on Hindu Law. Theory and Practice (2nd Ed.). Dhaka: Hira Publications. 